\title{
FACTORS FOR DEVELOPMENT INVESTMENT SUCCESSES IN THE HOLIDAY PROPERTY SECTOR
}

\author{
Jarosław Szreder \\ Faculty of Management \\ Pomeranian Academy in Stupsk \\ e-mail:jszreder@apion.pl \\ Piotr Walentynowicz \\ Institute of Organization and Management \\ Gdańsk University \\ e-mail: piotr.walentynowicz@ug.edu.pl
}

\begin{abstract}
The article attempts to identify, classify and evaluate the success factors of development projects implemented in the holiday property sector. The first part of the study presents development prospects for this market in Poland. The next part presents the idea of using key success factors in management. The empirical part presents the results of own research and the conclusions resulting therefrom. The analyses were based on the experience gained during the successful implementation of this type of projects and the opinions of their clients. The information presented in the literature on the subject was also helpful in developing the KCS list for the examined sector. In the authors' opinion, despite conducting the research in an unrepresentative manner, the resulting conclusions, which are qualitative, can be highly helpful in implementing such projects in practice and as a material for discussion in the process of educating students.
\end{abstract}

Key words: direct investment, developer, holiday property segment.

JEL Classification: R30, R31, G11.

Citation: Szreder, J., Walentynowicz, P. (2020). Factors for development investment successes in the holiday property sector. Real Estate Management and Valuation, 28(2), 1-12.

DOI: https://doi.org/10.1515/remav-2020-0011

\section{Introduction}

The holiday property market segment in Poland has been in a phase of dynamic growth for several years. Newer and more innovative projects are appearing on the market. The standard offer of developers from 8-10 years ago, when the basic product was usually a flat finished in the developer stage, in a multi-family building, located in a tourist-attractive town, no longer meets the requirements of investors operating in this market segment (www.rp.pl, 2019). The current activity of developers in this segment has its specificity, which is different from the standard activity of developers on the housing projects market.

For many years, one of the basic research directions in the science of management has been the trend of searching for answers to question regarding the basic factors behind the success of enterprises (Walentynowicz, 2005). It is also widely known that these differ significantly depending on the situational conditions of various economic activities. Thus, in line with this trend, the authors of the article put forward a thesis that operation by developers in the holiday property segment is much more demanding and is characterized by other success factors than conducting typical development activity in the housing segment. Accordingly, the purpose of the article is to identify and attempt to 
classify key success factors for development projects in the holiday property market. The basic research methods used in the article were: analysis and synthesis of the literature on the subject, analysis of the conditions of projects implemented by one of the authors in the past and present, as well as a survey of the customer reviews of these projects.

\section{Investing on the market of the residential and holiday properties}

Direct investment in the real estate market can take place in each of the market segments, i.e. in the residential, commercial, industrial, agricultural and special purpose segments. Research carried out in 2018 by the marketplace portal www.rynekpierwotny.pl shows that two-thirds of wealthy Polish people consider a housing investment as the best form of investing capital. Gold, stock exchange, investment funds, bank deposits, works of art and bonds took further positions (www.rynekpierwotny.pl, 2019). The above is due to the fact that, in recent years, housing investments have brought investors higher rates of return than bank deposits and have proved to be much safer than investment funds.

A steady increase in investment in housing for rent is being observed. In 2017, this percentage was $23 \%$ of buyers, while in 2018, it was already 28\% (www.businessinsider.com.pl, 2019). This is confirmed by the fact that one-third of the new flats purchased from developers were paid for in cash, of which two-thirds were bought for typically investment purposes. Only a third of the apartments for cash were bought for the buyers' own housing needs (www.businessinsider.com.pl, 2019). It seems that the popularity of a dwelling as an investment results from the firm belief that there is no greater investment risk or the need for specialized knowledge and experience. Other important arguments, especially for novice investors, are: the tangibility of the subject of the investment and the certainty of its ownership. Indirect investment in the real estate market (Kucharska-Stasiak, 2016a), consisting, for example, in the acquisition of investment certificates or units of investment funds issued on the basis of specific properties, despite the fact that it has a number of advantages (e.g. greater liquidity or lower capital intensity), does not give such opportunities. Investors' decisions to direct their potential towards the real estate market also result from the specific macroeconomic situation, i.e. the lack of alternative, equally favourable investments in times of low interest rates.

The holiday property market, next to the housing market, is an alternative segment for investors in which they can make investments. This segment should be included in the commercial real estate market due to the fact that it can be a capital investment and a source of income and profit for owners (Kucharska-Stasiak, 2016b). Figure 1 shows its structure.

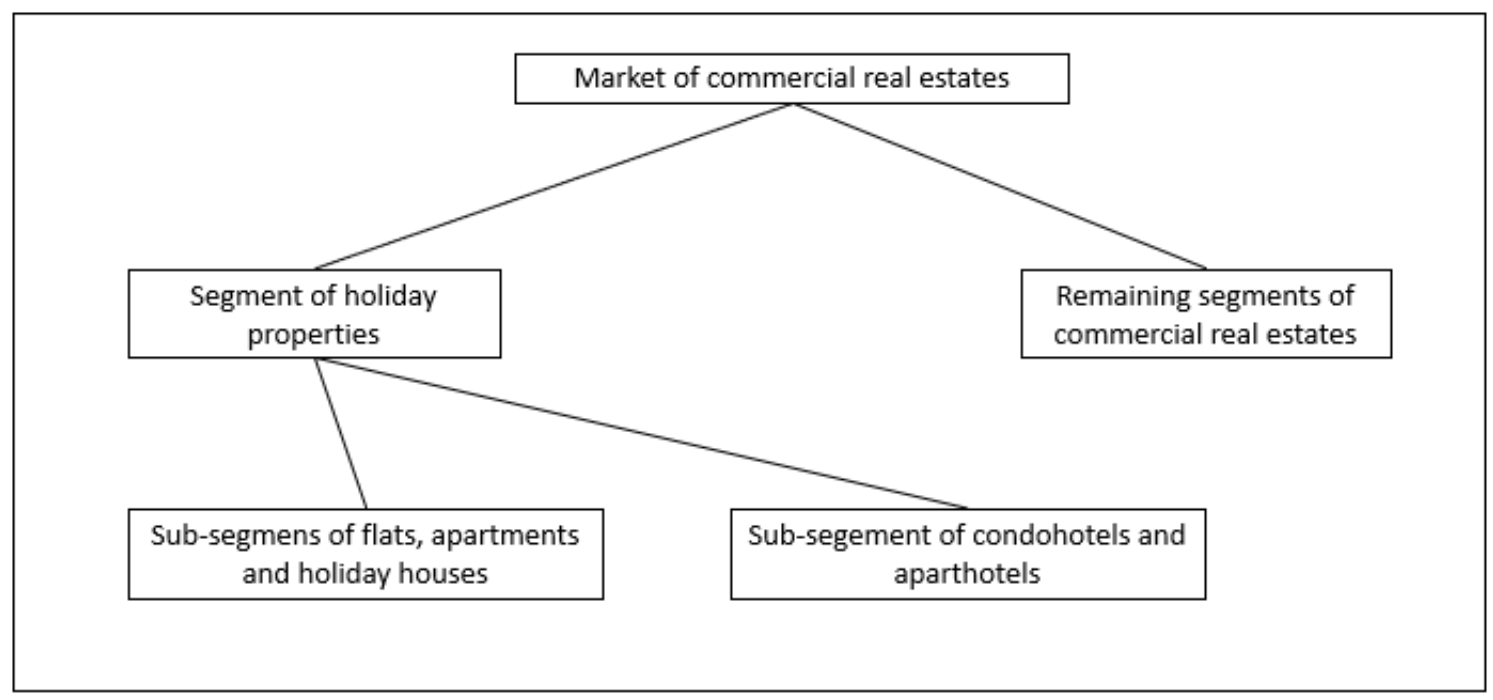

Fig. 1. Structure of the commercial real estate market. Source: own study.

It can be assumed that this segment consists of two sub-segments: apartments, apartments and holiday homes, as well as aparthotels and condohotels. The idea of aparthotels and condohotels boils down to the fact that customers become buyers of the hotel room or apartment, as a rule, for 
investment purposes, without participating in the land and without the possibility of registering for permanent residence (Szreder, 2014).

Direct investment in the holiday property segment in Poland has been growing dynamically in recent years. The most important positive macroeconomic factors affecting the development of this sector are: the good economic situation in the world and in Poland, the availability of financing sources and the persistently low level of interest rates. The next subsection discusses other significant conditions affecting the development of this segment of the real estate market in Poland.

\section{Conditions for the development of the holiday property market in Poland}

One of the most important conditions for the development of the holiday property investment sector is the fact that the disposable income of the society in Poland is growing. According to GUS (Central Statistic Office) data, in 2017, there was an increase in monthly disposable income per person in households by $6.3 \%$ compared to 2016 (GUS, 2018), while in 2018 - by 7.0\%. The evolution of this indicator over the last 13 years is shown in Figure 2.

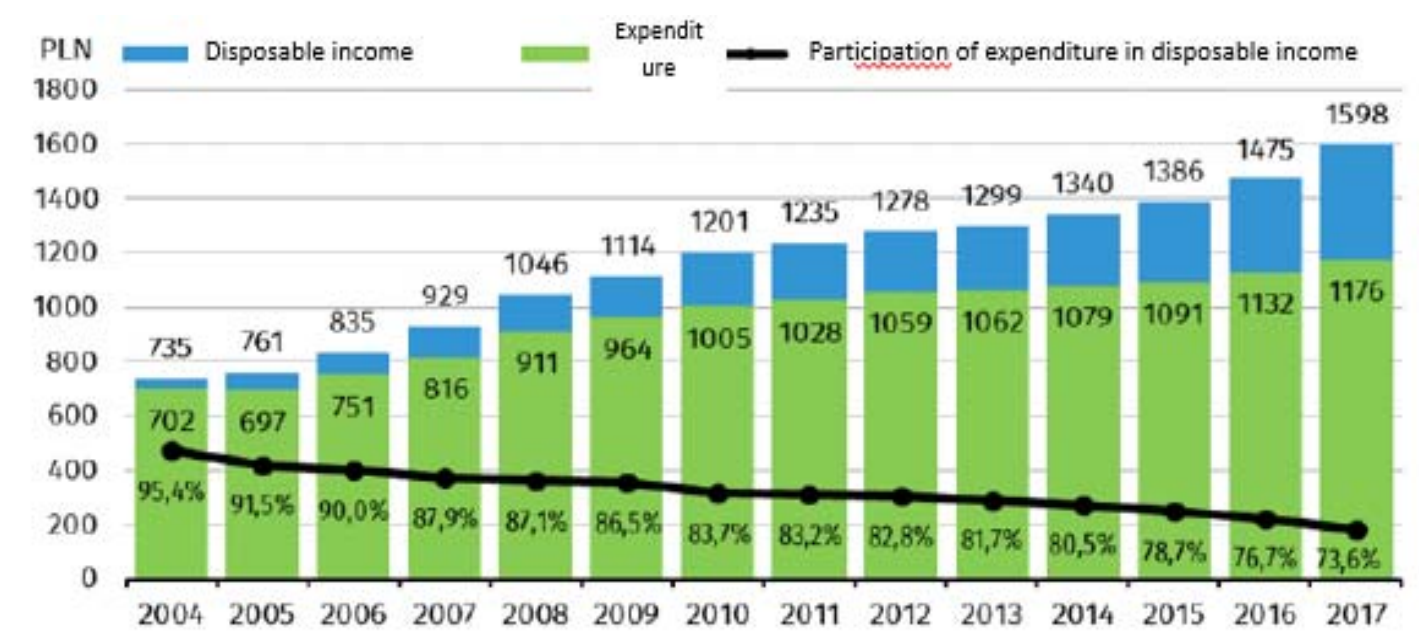

Fig. 2. The level of average monthly income and expenditure per capita in households and the share of expenditure in disposable income in the years 2004 - 2017. Source: GUS (Central Statistic Office) data.

Noteworthy is the steady annual decline in the share of expenditure in the disposable income of households from over $95 \%$ in 2004 to about $73 \%$ in 2017. This situation causes an increase in disposable income, and thus may increase the propensity to also invest in on the real estate market. The real increase in the level of remuneration (in the years $2017 / 2018$ by about $7 \%$ ), resulting in an increase in disposable income, means that investors are increasingly interested in buying higher-order goods, which can certainly include holiday properties. Investments in these properites are yet another way to invest capital surpluses.

Another condition that has an impact on the increase in the popularity of investing in the holiday property market is the constant development of tourism, which has a positive impact on the achieved rates of return, thus causing the development of this segment of real estate. Factors influencing the development of tourism can be divided into: demographic, infrastructural and economic (KoniecznaDomańska, 2007). Economic factors that can be considered the most important, affecting the volume of demand for tourist services, are: the income levels of the population, prices of tourist services and aspects of supply. The purchasing power of the population is mainly shaped by their income. Tourism appears in the structure of human spending after satisfying the consumption needs necessary for life. Only a high level of income allows households to satisfy free consumption, and thus also tourist consumption.

Data from the Ministry of Sport and Tourism and reports from professional tourist organizations (www.pot.gov.pl, www.pit.org.pl, 2019) indicate a steady increase in the volume of tourism in Poland in recent years (www.msit.gov.pl, 2019). And so, in the first half of 2018, compared to the same period of the previous year, the following significant indicators were noted, which are presented in Table 1. 


\section{S sciendo}

The above data, as well as data from previous years, indicate a continuous development of tourism in Poland. The number of foreign tourists arriving in Poland is constantly increasing. A definitely positive factor for investing in the holiday property sector is the change in the lifestyle of Polish people, who have been making more domestic trips every year. The share of expenditure of the population related to domestic trips is also growing dynamically.

Table 1

Basic statistical data on tourism in Poland for the first half of 2018

\begin{tabular}{lcc}
\hline \multicolumn{1}{c}{ Tested parameter } & In absolute numbers & $\begin{array}{c}\text { Dynamic of I half } \\
\text { of 2017/2018 }\end{array}$ \\
\hline Number of foreigners' arrivals to Poland & $41.8 \mathrm{mln}$ & $2.4 \%$ \\
\hline Number of foreigners' arrivals & $8.87 \mathrm{mln}$ & $6.6 \%$ \\
\hline $\begin{array}{l}\text { Expenses of foreigner tourists connected with stay in } \\
\text { Poland }\end{array}$ & $15.14 \mathrm{mld} \mathrm{PLN}$ & $5.8 \%$ \\
\hline Number of domectic journeys of Polish citizens & $19.7 \mathrm{mln}$ & $5.3 \%$ \\
\hline Number of domestic short-term journeys (weekend) & $13.9 \mathrm{mln}$ & $3.7 \%$ \\
\hline $\begin{array}{l}\text { Number of domestic long-term journeys (leave- } \\
\text { holiday) }\end{array}$ & $5.8 \mathrm{mln}$ & $9.4 \%$ \\
\hline $\begin{array}{l}\text { Expenses incurred in connection with domestic } \\
\text { journeys of Polish citizens }\end{array}$ & $9.7 \mathrm{mld} \mathrm{PLN}$ & $14.1 \%$ \\
\hline $\begin{array}{l}\text { Number of touristic journeys abroad taken by Polish } \\
\text { citizens }\end{array}$ & $5.3 \mathrm{mln}$ & $6.0 \%$ \\
\hline
\end{tabular}

Source: Internet on the website: www.msit.gov.pl.

Another important factor affecting the increase in tourist traffic and demand is the increase in the amount of free time (non-working days, holidays, length of paid holidays, holidays and school holidays). The information from the market and the authors' observations shows that the ban on Sunday trade causes an increase in weekend domestic tourist traffic.

Other demographic factors include marital status and a change in the family model from a large one to a smaller one, a general increase in the level of education of the population, a change in the lifestyle of young people, in particular to a more active, health-concious one with greater effort put into work and education, which regenerates the physical and mental strength of the body (SUCHECKI, 2016). It is also important to develop the model of modern life, the rush for the fashion for traveling, the need for prestige, imitation (Konieczna-Domańska, 2007).

Among the infrastructure factors positively influencing the development of tourism, the most important include the implementation of public infrastructure investments in and outside the tourist area, as well as constant development of transport, including increasingly popular low-cost airlines. The development of mobile technologies, Internet coverage and network marketing is also significant. The above conditions affect the increase in the popularity of tourist areas thanks to, among others, shortening travel time to destinations and developing the availability of information on them, which translates into a further increase in interest in the holiday property market.

\section{The essence of key success factors in business management}

Considerations regarding the factors of success and failure of enterprises in science and management practice have been carried out for over 40 years. One of the first entries on this subject in the world literature was In Search of Excellence by T. Peters and R. Waterman (1982). It presented the results of research on the success factors of 62 large, well-known and, in the opinion of the authors, wellmanaged American companies (Obłój, 2001). Since then, there has been a fashion for global research in management science (Ansoff, 1994; Collins 2001; Stankiewicz 2002; Dahlgaard- Park, Dahlgaard, 2006; Simon, 2010). There was also a wide discussion on this subject on the subject in the Polish literature in the 90s (Koźmiński, 1996; Bieniok, 1997; Kieżun, 1997; Dwojacki, 1995; Niestrój, Hadrian, 1999; Olszewska, 2000; Obłój 2003). The results of these studies are presented in more detail in: (Walentynowicz, 2005). In conclusion, most of these authors, in a general sense, included the following among the main success factors of enterprises operating at the turn of the century: 
1) better quality/price ratio than the competition, attractive to the client company offer,

2) the ability to see and take advantage of market opportunities, gain new markets,

3) close and friendly relations with clients,

4) efficient marketing mix (product, price, promotion and distribution),

5) good management system (including finances and costs) and competent management staff,

6) good human resources management system, skilful use of employee competences,

7) innovation in all areas of the company's business.

Recently, the ability to cooperate with business partners is also gaining importance (Czakon, 2012, p. 23 et seq.). However, it was very quickly observed that, although general considerations may be helpful in strategic management (Obłój, 2001), they have low application value in operational management in particular conditions of business operations. Therefore, research was started on the search for determinants of the success of enterprises under various situational conditions. These considerations are most often carried out by industry (service companies / manufacturing companies) (Zakrzewska-Bielawska, 2008; Gicała, Sobotka, 2017), depending on the size or type of business activity (Zarepur, 2001; Danielak, Gębska, 2017; Walentynowicz, Machel, 2018), for functional areas (managed strategic, marketing, finance, human resources or quality) (Jenster, 1987; Johnson, Friesen, 1995; Dirks, Wijn, 2002) or for various types of problem areas in the functioning of modern enterprises (implementation of IT systems), implementation of new management concepts, project management or crisis management) (Spałek, 2004; Wong, 2005; Zakrzewska-Bielawska 2007; Constantinos, 2012; Skalik, Strzelczyk, 2013; Wojnicka-Sycz, Sycz, 2016; Walentynowicz, 2016). There is a lot of literature on this subject.

It was also very quickly observed that, depending on the type of business activity, in accordance with the Pareto principle, several key factors are particularly important for the success of an enterprise (Eisenhardt I Zbaraki, 1992; Strategor, 1996; Gates, 2010; Knopp, Szmal, 1999; Gierszewska, Romanowska, 2003; Skawińska, Zalewski, 2016).

Considering development activities primarily as project activities, the most important factors in project management in general are (Spałek, 2004, Skalik, Strzelczyk, 2013; Trocki, 2013):

1) precise specification of the project recipients' requirements,

2) clear and precise definition of the project (goals, scope, costs),

3) proper project implementation methodology (based on the standards of individual global methodologies),

4) competences of project managers,

5) proper selection and motivation of project team members,

6) ensuring adequate resources necessary for project implementation,

7) skilful project risk management,

8) ensuring an adequate level of communication in the project and cooperation of the persons participating in it,

9) consistent implementation of planned activities and control of deadlines and budgets for their implementation,

10) appropriate, quick and efficient response to emerging problems (being a derivative of project management competences).

Simultaneously, the set of success factors in development activities should be supplemented with issues such as (Lachiewicz, Wojsa, 2014; Szreder 2015; Szreder, Walentynowicz, Sycz, 2019):

1) a suitable investment location attractive to clients,

2) an attractive final product for customers (design, quality, usability, purchase and operation costs, attractive development of the building environment),

3) preceding the decision on project implementation with comprehensive marketing research and a study of the project's feasibility conditions justifying the economic sense of the project implementation,

4) the ability to cooperate and profitable relations with various types of stakeholders and entities involved in the implementation of the project,

5) the ability to obtain appropriate financial resources for the project,

6) the developer's experience and its relevant image on the market. 
Therefore, in line with the above trends in scientific considerations, the authors of the article set out to identify and present the key success factors of development activity in the holiday property segment.

\section{Classification of success factors on the holiday property market}

Competition for Polish investments on the holiday property market is the market for these properties in EU countries. Until recently, the most popular directions for making this type of investment were Spain, Greece and Croatia (www.rp.pl, 2019). However, the unstable political situation has caused the coastal regions of countries such as Bulgaria, Estonia and Romania to also becomeincreasingly popular. Figure 3 presents the motives for buying a holiday property regardless of location.

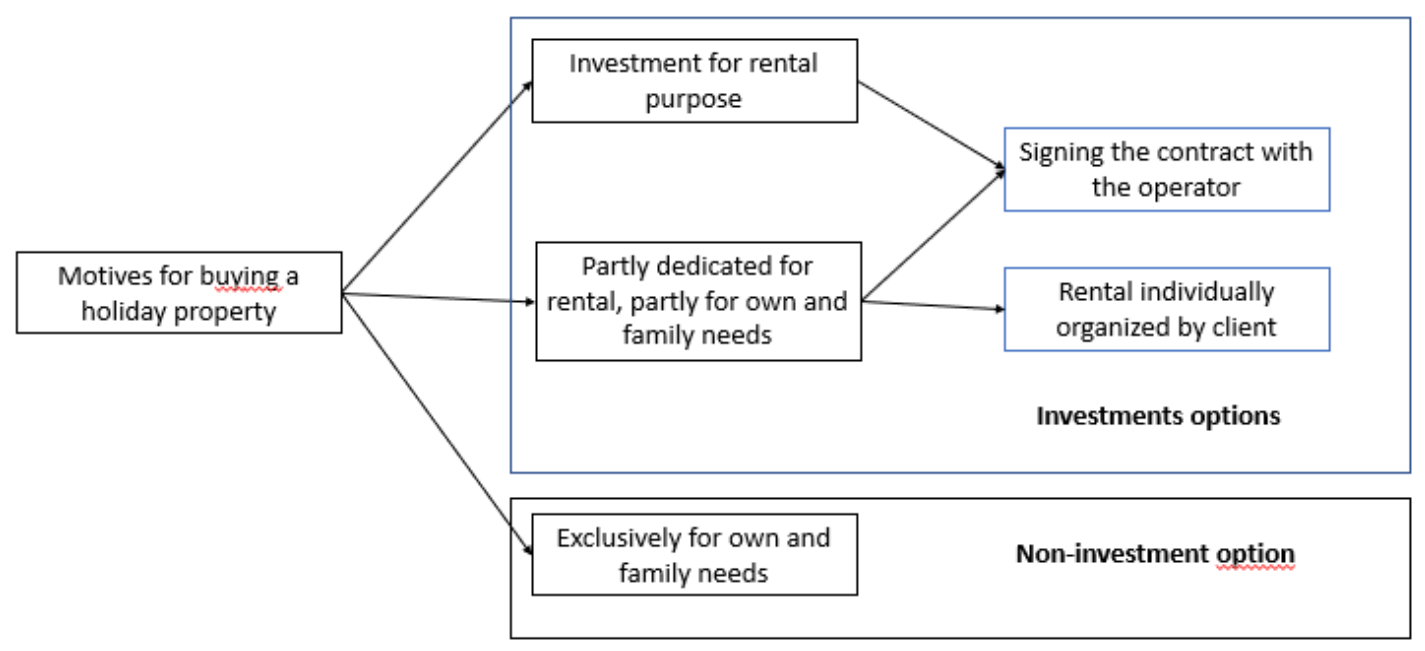

Fig 3. Motives for buying a holiday property. Source: own study.

The predominance of disadvantages over advantages of foreign investments and the constant development of tourist traffic in Poland mean that the holiday property market in Poland is in a growth phase. The authors' observations show that, in the recent years, foreign investors have also been making significant investments in holiday properties in Poland. Investors treat these investments as a safe form of investing capital. Some investors of the examined projects are foreigners.

Shopping or investments usually take place in popular and well-known tourist destinations. The choice of less known (not very popular) cities in which development is anticipated may, however, result in potentially much higher profits (WWW.RP.PL; 2019).

Table 2 shows the basic success factors for development projects in the holiday property segment presented. They were identified based on the analysis and synthesis of literature sources and the authors' experience. To facilitate analysis, the factors have been grouped into five thematic areas regarding the offered product, location attractiveness of the investment, in the area of market-wide factors, in the area of the developer's market competitiveness and in the area of organization and management of the development project.

Table 2

A set of analyzed success factors

L.p.

Factor of success

IN THE PRODUCT AREA

1. The attractiveness of the architectural design of the product (house / apartment)

2. Standard of finishing the product offered by the developer

3. The number and standard of additional attractions prepared by the developer at the purchase price of the basic product

4. Proper arrangement of space in the implemented investment

5. The right size of the house/apartment guarantees the best sales to the developer and the highest rate of return on the investment for the developer's clients 
6. It is possible to individually arrange the interior of the purchased product (house / apartment) by the developer of the client

7. Possibility of offering the investor a finished product in a turnkey system, i.e. a complete one that meets the rental requirements

8. $\quad$ Product price

IN THE AREA OF LOCATIONAL INVESTMENT ATTRACTIVENESS

1. Tourist attractiveness of the investment location - a fashionable destination

2. Location attractiveness in terms of the environment, e.g. proximity to the sea, mountains, lakes, investment intimacy

3. Impact of planned significant public infrastructure investments that may have a positive impact on the investment

4. Location of the investment in terms of ease of access to it

\section{IN THE AREA OF GENERAL FACTORS}

1. Prestige associated with a given investment

2. Potential increase in property/investment value over time

3. Good prospects related to the development of the tourist market in a given area

4. Possibility to control the property / investment (despite the spatial distance)

5. Investment profitability, real and anticipated rates of return

\section{IN THE AREA OF THE DEVELOPER'S MARKET COMPETITIVENESS}

1. The developer's experience in previous implementations of similar investments

2. The developer's (operator's) experience in managing and renting built real estate

3. Positive feedback about the developer / operator and the level of services rendered

4. The economic and financial condition of the developer and the related financial security of the implemented investment

5. Offering a rental / management contract with the developer or an operator of his choice

6. Customer profit guarantee provided by the developer in the first period of rental activity

7. Ability to obtain appropriate financial resources for the implementation of the investment by the developer

\section{IN THE AREA OF ORGANIZATION AND DEVELOPMENT PROJECT MANAGEMENT}

1. Ability to search and acquire attractive areas for investment locations

2. Conducting reliable market analyses documenting the potential profitability of the project

3. Efficient implementation of the investment by the developer, meeting deadlines

4. Investment implementation cost management, budgeting

5. Activity in the field of investment promotion, proper marketing

6. Professional customer / investor service at the property sale stage

7. Proper, investor-friendly organization of rental activities

8. Rental costs (charged to clients' investment result)

9. Activity in the promotion of rental activities, proper marketing

Source: own study.

The next stage of the research project was to analyze the assessments of individual factors made by selected clients of development projects implemented by one of the authors. The respondents were selected from a group of natural persons (30 surveys) and representatives of legal entities (companies) ( 2 surveys), who have purchased a flat or a holiday house from the developer in the last three years. A total of 85 questionnaires were sent, with 32 received back. The research sample was selected in a convenient manner (Szreder, 2004). The survey did not have a metric because the research did not assume any analyses based on individual customer cross-sections. The respondents had to assess the importance of individual factors for the success of a development project in the holiday property 
segment on a scale of 1 to 3 . The research was conducted at the beginning of 2019. For most respondents, the investment was the main motive for the purchase.

\section{Findings}

The rank of individual factors was determined based on the sum of respondents' indications. The results obtained are presented in Table 3.

Table 3

Results of surveys carried out

\begin{tabular}{|c|c|c|}
\hline $\begin{array}{l}\text { Order } \\
\text { number }\end{array}$ & Factor tested & $\begin{array}{c}\text { Number } \\
\text { of } \\
\text { readings }\end{array}$ \\
\hline 1. & $\begin{array}{l}\text { The experience of the developer (operator) in managing and renting built real } \\
\text { estate }\end{array}$ & 92 \\
\hline 2. & Product price & 92 \\
\hline 3. & Return on investments, real and projected rates of return & 88 \\
\hline 4. & Rental costs (charged to clients' investment result) & 88 \\
\hline 5. & $\begin{array}{l}\text { Location attractiveness in terms } f \text { the environment, e.g. proximity to the sea, } \\
\text { mountains, lakes, investment intimacy }\end{array}$ & 88 \\
\hline 6. & Proper, investor-friendly organization of rental activities & 84 \\
\hline 7. & $\begin{array}{l}\text { Conducting reliable market analyses documenting the potential profitability of } \\
\text { the project }\end{array}$ & 84 \\
\hline 8. & $\begin{array}{l}\text { The number and standard of additional attractions prepared by the developer } \\
\text { at the purchase price of the basic product }\end{array}$ & 84 \\
\hline 9. & The developer's experience in previous implementations of similar investments & 82 \\
\hline 10. & Standard of finishing the product offered by the developer & 82 \\
\hline 11. & $\begin{array}{l}\text { The client's profit guarantee is granted by the developer in the first period of } \\
\text { the rental activity }\end{array}$ & 80 \\
\hline 12. & $\begin{array}{l}\text { The attractiveness of the architectural design of the product (house / } \\
\text { apartment) }\end{array}$ & 80 \\
\hline 13. & $\begin{array}{l}\text { The right size of the house / apartment guarantees the best sales to the } \\
\text { developer and the highest rate of return on investment for the developer's } \\
\text { clients }\end{array}$ & 80 \\
\hline 14. & Good prospects related to the development of the tourist market in a given area & 80 \\
\hline 15. & $\begin{array}{l}\text { Efficient investment implementation by the developer, meeting investment } \\
\text { deadlines }\end{array}$ & 78 \\
\hline 16. & Activity in the promotion of rental activities, proper marketing & 76 \\
\hline 17. & Potential increase in property / investment value over time & 76 \\
\hline 18. & $\begin{array}{l}\text { The economic and financial condition of the developer and the related financial } \\
\text { security of the implemented investment }\end{array}$ & 74 \\
\hline 19. & Activity in the field of investment promotion, proper marketing & 74 \\
\hline 20. & Location of the investment in terms of ease of access to it & 72 \\
\hline 21. & Ability to control the property / investment despite the spatial remoteness & 70 \\
\hline 22. & Managing investment implementation costs, staying within the planned budget & 70 \\
\hline 23. & Proper arrangement of space in the implemented investment & 70 \\
\hline 24. & $\begin{array}{l}\text { Offering a rental / management contract with the developer or an operator of } \\
\text { his choice }\end{array}$ & 70 \\
\hline 25. & $\begin{array}{l}\text { Possibility of offering the investor a finished product in a turnkey system, i.e. a } \\
\text { complete one that meets the rental requirements }\end{array}$ & 70 \\
\hline
\end{tabular}




\begin{tabular}{llc}
\hline 26. & $\begin{array}{l}\text { Positive feedback about the developer / operator and the level of services } \\
\text { rendered }\end{array}$ & 68 \\
\hline 27. & Tourist attractiveness of the investment location - a fashionable destination & 66 \\
\hline 28. & $\begin{array}{l}\text { Impact of planned significant public infrastructure investments that may have a } \\
\text { positive impact on the investment }\end{array}$ & 64 \\
\hline 29. & Professional customer / investor service at the property sale stage & 62 \\
\hline 30. & $\begin{array}{l}\text { It is possible to individually arrange the interior of the purchased product } \\
\text { (house / apartment) by the developer of the client }\end{array}$ & 62 \\
\hline 31. & Ability to search and acquire attractive areas for investment locations & 58 \\
\hline 32. & $\begin{array}{l}\text { Ability to obtain appropriate financial resources for the implementation of the } \\
\text { investment by the developer }\end{array}$ & 50 \\
\hline 33. & Prestige associated with a given investment & 38
\end{tabular}

Source: own study based on conducted research.

The following conclusions can be drawn from the study. First of all, it can be observed that the success factors of development projects in the holiday property segment intended primarily for clients' investment purposes differ significantly from the success factors of development projects in other markets. This conclusion confirms the thesis formulated by the authors at the beginning of the study. As it results from Table 3, in addition to strictly economic and financial factors, the attractiveness of the product (design and location) as well as the related leisure infrastructure is also of great importance. Moreover, the conditions for organizing subsequent rental services for real estate are very important. That is why the experience and competences of the developer implementing the investment are so imperative. The least important for respondents is where the developer will obtain funds to finance the investment from and the prestige associated with the fact of having it. Secondly, it can be clearly seen that in the opinion of the respondents, most of the identified factors are of great importance for the success of this type of investment. This would confirm the hypothesis that such projects are one of the most complex on the real estate market and many aspects should be taken into account in their implementation. A developer implementing this type of investment should have special competences. Thirdly, in connection with the above, it is difficult to indicate selected success factors for these types of projects, and the authors recommend that developers use the full list of factors identified in the research when implementing such an investment.

\section{Summary}

The conducted research allowed key factors having the most serious impact on the sucessful implementation of development projects on the holiday property market to be identified and classified. Research clearly confirms the thesis that operating in the holiday property segment is much more demanding to developers and is characterized by other success factors than conducting typical activity in the housing segment.

In light of the thesis, it should be pointed out that, for this segment of business operations, more potential success factors can be identified than in ordinary housing development activity. In addition, many of the aspects presented will not occur in the ordinary housing market, where other factors determine the success of developers.

The authors are aware that the results of the research cannot be considered as representative. Nevertheless, they can be useful for developers preparing new investment projects in the holiday property segment. That is why they encourage other scientists to conduct their own research on this topic and to discuss the topic in subsequent publications presented in REMV.

\section{Literature and other sources}

Ansoff, H. I. (1994), A contingent paradigm for success of complex organizations (in:) Milestones in Management vol. 5, Schaffer Poeschel, Switzerland.

Bieniok, H., et al. (1997), Metody sprawnego zarządzania (Methods of efficient management). AW „Placet", Warszawa. 
Collins, J. C. (2001). Od dobrego do wielkiego. Czynniki trwałego rozwoju i zwycięstwa firm (From good to great. Factors of sustainable development and companies' victory). J. Santorski, Wydawnictwa Biznesowe.

Constantinos, J.S. (2012). Organisational Key Success Factors for Implementing SCM/ERP Systems to Support Decision Making. Journal of Decision Systems, 10(1), 49-64.

Czakon, W. (2012). Sieci w zarządzaniu strategicznym (Networks in strategic management). Wyd. Wolters Kluwer.

Dahlgaard-Park, S. M., \& Dahlgaard, J. J. (2006). In Search of Excellence - Past, Present and Future [in:] Herbert Schnauber (ed.), Kreativ und Konsequent, p.57-84, Carl Hanser Verlag GmbH, https://pdfs.semanticscholar.org/1e34/10464e26234e46dfd8417b3d8b6bd713a3a5.pdf, dostęp 10.03.2019.

Danielak W., Gębska K. (2017), Bariery rozwoju i kluczowe czynniki sukcesu małych i średnich Przedsiębiorstw (Barriers to development and key success factors for small and medium-sized enterprises), Zeszyty Naukowe Polskiego Towarzystwa Ekonomicznego w Zielonej Górze 2017, nr 7.

Dirks, P., \& Wijn, M. (2002). Strategic Control: Meshing Critical success Factors with the Balanced Scorecard. Long Range Planning, 35(4), 407-427.

Dwojacki, P. (1995). Czynniki sukcesu polskich przedsiębiorstw (w:) Sukces i porażka w biznesie. Polskie doświadczenia lat dziewięćdziesiątych (Success factors of Polish enterprises (in :) Success and failure in business. Polish experiences of the nineties), GIG Instytut Zarzadzania i Rozwoju, Gdańsk.

Eisenhardt, K., \& Zbaracki, M. (1992). Strategic decision making. Strategic Management Journal, 13(S2), 17-37.

Gates, L.P. (2010), Strategic Planning with Critical Success Factors and Future Scenarios: An Integrated Strategic Planning Framework, Technical Report, CMU/SEI-2010-TR-037, ESC-TR-2010-102, November. https://doi.org/10.21236/ADA532574

Gicała, M., \& Sobotka A. (2017). Jaką strategię obrać? Kluczowe czynniki sukcesu według badań. Część 1 (Which strategy to take? Key success factors according to research. Part 1, Bullder, nr 66.

Gierszewska, G., \& Romanowska, M. (2003). Analiza strategiczna przedsiębiorstwa (Strategic analysis of the company). PWE.

Internet on websites: www.businessinsider.com.pl; dostęp z dnia 20.02.2019.

Internet on websites:www.msit.gov.pl; Podstawowe dane statystyczne z turystyki za I pótrocze 2018 (Basic statistical data in tourism for the first half of 2018); dostęp 21.02.2019.

Internet on websites:www.pot.gov.pl; dostęp 21.02.2019.

Internet on websites: www.pit.org.pl; dostęp 20.02.2019.

Internet on websites: www.rp.pl; dostęp 15.03.2019.

Internet on websites: www.rynekpierwotny.pl; dostęp 20.02.2019.

Internet on websites:: www.stat.gov.pl; Sytuacja gospodarstw domowych w 2017 r. w świetle wyników badania budżetów gospodarstw domowych (The situation of households in 2017 in the light of the results household budget surveys); dostęp 15.02.2019.

Jenster, P. (1987). Using Critical Success Factors in Planning. Long Range Planning, 20(4), 102-109. https://doi.org/10.1016/0024-6301(87)90160-9

Johnson, J., \& Friesen, M. (1995). The Success Paradigm: Creating Organizational Effectiveness Through Quality and Strategy. Quorum Books.

Kieżun, W. (1997). Sprawne zarządzanie organizacją (Efficient organization management). Wyd. SGH.

Knop, L., \& Szmal, A. (1999). Kluczowe czynniki sukcesu w budowaniu przewagi konkurencyjnej (Key success factors in building a competitive advantage) (w:) Pyka J. (red.) Nowoczesność przemysłu i usług - uwarunkowania regionalne (Modernity of industry and services - regional conditions), TNOiK, Katowice.

Konieczna - Domańska, A. (2007). Gospodarka turystyczna. Wybrane zagadnienia (Tourism economy. Selected Issues). Kanon.

Koźmiński, A. K. (1996), Badanie procesów zarządzania w kontekście wyzwań przyszłości (Researching management processes in the context of challenges of the future), Master of Business Administration $n \mathrm{nr} 3$.

Kucharska-Stasiak, E. (2016). Ekonomiczny wymiar nieruchomości (The economic dimension of real estate). PWN. 
Lachiewicz, S., \& Wojsa, A. (2014), Czynniki sukcesu w procesie realizacji projektów inwestycyjnych $\mathrm{w}$ sektorze nieruchomości komercyjnych (Success factors in the process of investment projects in the sector commercial real estate), Zeszyty Naukowe Politechniki Łódzkiej, Organizacja i Zarządzanie, z. 57.

Niestrój, R., \& Hadrian, P. (1999). Czynniki sukcesu jako wyznaczniki orientacji przedsiębiorstwa (Success factors as determinants of the company's orientation), Marketing i Rynek nr 8-9.

Obłój, K. (2001). Strategia organizacji. W poszukiwaniu trwałej przewagi konkurencyjnej (Organization strategy. In search of a lasting competitive advantage). PWE.

Obłój, K. (2003), Strategie sukcesu: jak proste reguły pozwalają wygrać (Success strategies: how simple rules allow you to win), Harvard Business Review Polska, marzec.

Olszewska, B. (2000), Istota, miary, czynniki sukcesów i porażek przedsiębiorstw (w:) Źródła sukcesów i porażek przedsiębiorstw. Aspekt strategiczny (The essence, measures, factors of successes and failures of enterprises (in:) Sources of successes and failures of enterprises. The strategic aspect), Prace Naukowe AE we Wroctawiu nr 870.

Peters, T., \& Waterman, R. (1982). In Search of Excellence: Lessons from America's Best-Run Companies. HarperCollins Publishers Inc.

Simon, H., \& Dietl, J. (2009). Tajemniczy mistrzowie XXI wieku (Mysterious masters of the 21st century). Difin.

Skalik J., \& Strzelczyk A. (2013). Kluczowe czynniki sukcesu w zarządzaniu projektami informatycznymi (Key success factors in IT project management), Zarządzanie $i$ Finanse, nr 4.

Skawińska E., \& Zalewski R. (2016). Konkurencyjność - kluczowe czynniki sukcesu przedsiębiorstw XXI w. (Competitiveness - key success factors for 21st century enterprises), Przeglad Organizacji nr 3.

Spałek, S. (2004). Krytyczne czynniki sukcesu w zarządzaniu projektami (Critical success factors in project management). Wydawnictwo Politechniki Ślaskiej.

Stankiewicz, M. J. (2002), Konkurencyjność przedsiębiorstw. Budowanie konkurencyjności przedsiębiorstwa $\mathrm{w}$ warunkach globalizacji (Competitiveness of enterprises. Building company's competitiveness in the conditions of globalization), Wyd. Dom Organizatora, TNOiK, Torun.

Strategor, (1996), Zarządzanie firmą. Strategie. Struktury. Decyzje. Tożsamość (Company management. Strategies. Structure. Decisions. Identity), PWE, Warszawa.

Szreder, M. (2004). Metody i techniki sondażowych badań opinii (Methods and techniques of opinion polls). PWE.

Szreder, J., Walentynowicz, P., \& Sycz, P. (2019), Adaptative Project Framework as a Development Project Management Method on the Example of the Kashubska Ostoja Project. Real Estate Management and Valuation 27(1). https://doi.org/10.2478/remav-2019-0001

Szreder J. (2015). Czynniki sukcesu $\mathrm{w}$ inwestycjach typu land development (Success factors in land development investments). Świat Nieruchomości, World of Real Estate Journal, Nr 3.

Szreder, J. (2014). Ocena ofert inwestycyjnych na rynku nieruchomości wakacyjnych w Polsce (Evaluation of investment offers on the holiday real estate market in Poland), Studia i Prace Wydziału Nauk Ekonomicznych i Zarzadzania 36(1), Szczecin.

Suchecki, K. (2016). Wydatki na turystykę w budżecie polskich gospodarstw domowych (Expenditure on tourism in the budget of Polish households). Studia Ekonomiczne.Zeszyty Naukowe Uniwersytetu Ekonomicznego w Katowicach.

Trocki, M. (red.) (2013). Nowoczesne zarządzanie projektami (Modern project management), PWE, Warszawa.

Walentynowicz, P. (2005). Czynniki sukcesu i porażki współczesnych przedsiębiorstw - analiza wybranych case studies (w:) Sukces organizacji. Ujęcie zasobowe i procesowe (Factors of success and failure of contemporary enterprises - analysis of selectedcase studies (in:) Organization's success. Resource and process depiction). Prace i Materiaty WZ UG nr 5, Sopot.

Walentynowicz, P. (2016). Kluczowe czynniki sukcesu implementacji Lean Management w przedsiębiorstwie (Key success factors in Lean Management implementation in the enterprise) (w:) Zakrzewska-Bielawska A. (red.) Stan i perspektywy rozwoju nauk o zarządzaniu: wybrane problemy (Status and prospects for the development of management sciences: selected problems), TNOIK, Wyd. Dom Organizatora, Torun. 
Walentynowicz P., \& Machel W. (2018). Wykorzystanie analizy KCS w procesie podnoszenia konkurencyjności małego przedsiębiorstwa na przykładzie Busprestige Premium Sp. z o.o. (The use of KCS analysis in the lifting proces the competitiveness of a small enterprise on the example of Busprestige Premium Ltd. Company), Zarządzanie i Finanse nr 4.

Wojnicka-Sycz E., \& Sycz P. (2016), Public Innovation Policy and Other Determinants of Innovativeness in Poland; The Innovation Journal: The Public Sector Innovation Journal 21(3), No 3.

Wong, K. Y. (2005). Critical Success Factors for Implementing Knowledge Management in Small and Medium Enterprises. Industrial Management \& Data Systems, 105(3), 261-279.

Zakrzewska-Bielawska, A. (2007). Czynniki sukcesu dużych polskich firm produkcyjnych (w:) Sukces organizacji. Uwarunkowania wewnętrzne i zewnętrzne (Success factors for large Polish manufacturing companies; in: Success organization. Internal and external conditions). Prace $i$ Materiaty Wydziatu Zarządzania Uniwersytetu Gdańskiego, Sopot.

Zakrzewska-Bielawska, A. (2008). Zarządzanie w kryzysie (Management in a crisis) (w:) Staniec I., Zawiła-Niedźwiecki J. (red.) Zarządzanie ryzykiem operacyjnym (Operational risk management), Wyd. C.H. Beck, Warszawa.

Zarepur J. (2001), Information management systems and critical success factors in small agencies. Ravesh Magazine, No. 68. 